\title{
IMMUNOLOGICAL RELATEDNESS OF STARFISH AND FISH HEXOSE 6-PHOSPHATE DEHYDROGENASES
}

\author{
SAMUEL H. HORI, YOSHIKAZU SADO \\ AND NORIMASA MATSUOKA \\ Department of Zoology, Faculty of Science, Hokkaido University, \\ Sapporo 060
}

Received April 30, 1977

In animal kingdom the enzymes having glucose 6-phosphate dehydrogenase activity exist in two distinct molecular forms; one is glucose 6-phosphate dehydrogenase (G6PD) and the other is the enzyme known as glucose dehydrogenase (Beutler and Morrison 1967) or hexose 6-phosphate dehydrogenase (H6PD; Ohno et al. 1966). They differ strikingly in kinetics, immunological properties, and chromatographic and electrophoretic behaviors (Beutler and Morrison 1967; Hori et al. 1975; Kimura and Yamashita 1972; Mandula et al. 1970; Srivastava et al. 1969). Despite such differences, however, it has been predicted that they share a common ancester and that the time of divergence might be near the beginning of vertebrate evolution (Stegeman and Goldberg 1971; Yamauchi and Goldberg 1973).

Recently, we have found in echinoderms an enzyme which possesses kinetic properties strikingly similar to those of vertebrate $\mathrm{H} 6 \mathrm{PD}$ and suggested another possibility that the origin of H6PD might be traced back to near the beginning of or before echinoderm evolution (Mochizuki and Hori 1976). However, the similarity in catalytic properties does not necessarily mean the homology of the molecules (Campbell et al. 1973; Rutter 1965). Hence, it is probable that starfish and vertebrate H6PD might be analogous molecules, having independent evolutionary origins. In order to rule out such possibility an attempt was made in the present study to demonstrate immunological relatedness of starfish and fish H6PD with rabbit antibody elicited to crucian carp H6PD.

\section{MATERIALS AND METHODS}

H6PD were partially purified from the livers of crucian carps (Carassius carassius) and from the pyloric caeca of starfish (Asterias amurensis) by the methods reported elsewhere (Sado and Hori 1976; Matsuoka et al. 1977). The starfish H6PD sample thus prepared contained both native (mol. wt. 200,000) and degraded $(100,000)$ forms of the enzyme (Matsuoka et al. 1977).

Rabbit antisera against crucian carp $\mathrm{H} 6 \mathrm{PD}$ were prepared as follows: a mixture of $1 \mathrm{ml}$ of H6PD (2.5 units, $0.36 \mathrm{mg}$ protein) and $1 \mathrm{ml}$ of Freund's complete adjuvant was injected intramuscularly into a rabbit. After 3,4 and 24 weeks, the rabbit was given booster injections of the mixture and bled 1 week after the last injection. The 
antisera were treated with ammonium sulfate at $40 \%$ saturation, and the resulting precipitate was subjected to gel filtration on Ultrogel AcA 34 (LKB) for separation of immune IgG fractions as follows: samples were placed on a $2.5 \times 95 \mathrm{~cm}$ column and eluted with $20 \mathrm{mM}$ tris- $\mathrm{HCl}$ buffer, $\mathrm{pH} 7.4$ containing $1 \mathrm{mM}$ EDTA and $0.5 \mathrm{M}$ ammonium sulfate. The flow rate was $30 \mathrm{ml}$ per hour and fractions of $10 \mathrm{ml}$ were collected. The fractions containing IgG were concentrated with an Amicon Diaflo XM-50 membrane. Normal IgG fractions were also prepared by the same method. Electrophoresis and enzyme assays were performed by the previous methods (Hori and Sado 1974). One unit of activity was defined as the amount of enzyme that reduced $1 \mu \mathrm{mol}$ of NADP per min at $21^{\circ} \mathrm{C}$.

\section{RESULTS AND CONCLUSION}

Antibody against crucian carp H6PD precipitated the specific antigen effectively, but not starfish H6PD at all. It was found, however, that the electrophoretic mobility of starfish H6PD was drastically modified after contact with antibody as shown in Fig. 1. The mobility of starfish H6PD relative to that of bromophenol blue was 0.19 in the absence or presence of normal IgG, but was zero in the presence of immune IgG. This suggests the binding of antibody to H6PD, and hence the immunological relatedness of starfish and fish H6PD. To substantiate this finding, three series of experiments were performed as follows:

(1) Neutralization tests. Figures $2 \mathrm{~A}$ and $2 \mathrm{~B}$ show typical neutralization curves obtained when increasing amounts of antibody were added to a given amount of (A) crucian carp H6PD or (B) starfish H6PD. As is evident in these figures, both fish and starfish H6PD are active on G6P and deoxyG6P, but the antibody to fish H6PD had a multiple effect on the enzyme activities; i.e., the antibody inhibited the activity on

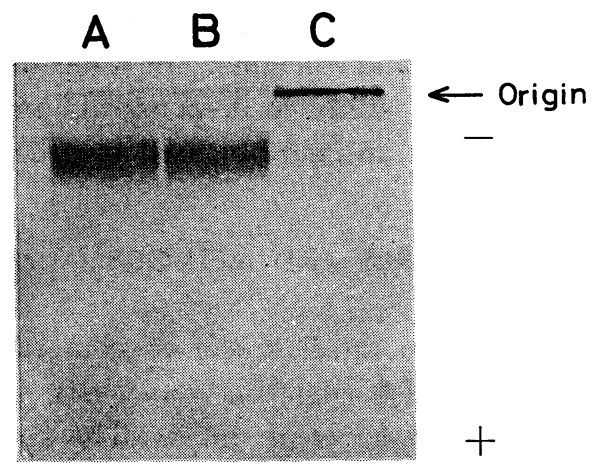

Fig. 1. Effect of anti-crucian carp H6PD antibody on the electrophoretic mobility of starfish H6PD. Starfish H6PD (8 milliunits) was electrophoresed before (A) and after mixing with $20 \mu 1$ of either normal IgG fraction (B) or anti-crucian carp H6PD IgG fraction (C). The gels were stained for enzyme activity by the method previously reported (Hori and Sado 1974). 


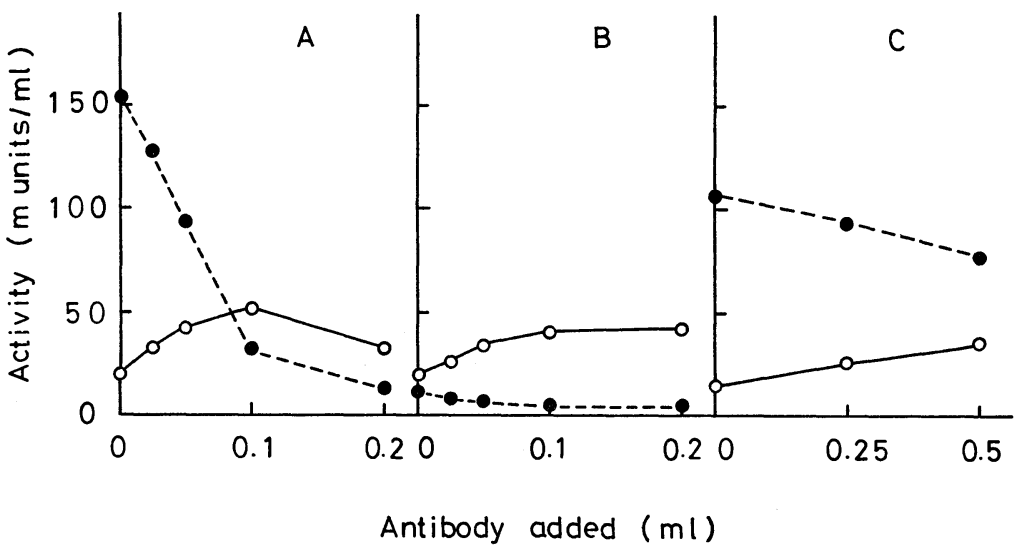

Fig. 2. Effects of anti-H6PD antibody on the G6P (O-O) and deoxyG6P dehydrogenating activities of specific and heterologous antigens. Crucian carp H6PD (A) or starfish H6PD (B) was incubated with increasing amounts of the immune IgG fraction at $4^{\circ} \mathrm{C}$ overnight and the enzyme activities were assayed at $21^{\circ} \mathrm{C}$ and $\mathrm{pH} 7.5$ with NADP and G6P or deoxyG6P as substrates. In (C), crucian carp H6PD was incubated with the antibody once bound to starfish H6PD (see text), and its activity was assayed as in (B).

deoxyG6P, but stimulated the activity on G6P.

(2) Separation of the starfish H6PD-antibody complexes. The starfish H6PD and the antibody were mixed, allowed to stand for $3 \mathrm{~h}$ at $4^{\circ} \mathrm{C}$ and subjected to gel filtration on Ultrogel AcA 34. Elution diagram of the mixture of antibody and starfish H6PD (Fig. 3C) showed two activity peaks in the positions distinctly different from those shown with starfish H6PD alone (Fig. 3A) or with the mixture of H6PD and normal IgG fractions (Fig. 3B).

The mixture of antibody and starfish samples containing the degraded H6PD alone showed a single activity peak at the same position as the minor peak obtained with the mixture of antibody and native plus degraded H6PD, thus indicating that the minor peak represented the complexes of antibody and degraded H6PD. These findings strongly suggest that the starfish and fish H6PD share at least one antigenic determinant in common and that the degraded form of starfish H6PD retained not only the enzymatic activity, but also its antigenicity, if not completely.

The molecular weights of the major and minor complexes obtained with the antibodyH6PD mixture were estimated from the calibration curve (Fig. 4) about 500,000 and 200,000 , respectively. It was not possible to speculate the exact molecular ratios of IgG and starfish H6PD in their complexes from these values, since both rabbit IgG and starfish H6PD did not conform to the standard $\mathrm{V}_{\mathrm{e}}-\mathrm{log}$ mol. wt. relationship.

(3) Properties of the antibody bound to starfish H6PD. In order to manifest that the antibody bound to starfish H6PD is the one specific for crucian carp H6PD, the major fractions obtained in the above experiments which contained the native H6PDantibody complex (this sample was electrophoretically free of unreacted IgG) were treated at $56^{\circ} \mathrm{C}$ for $30 \mathrm{~min}$ and their potencies to bind to the fish H6PD were examined. 


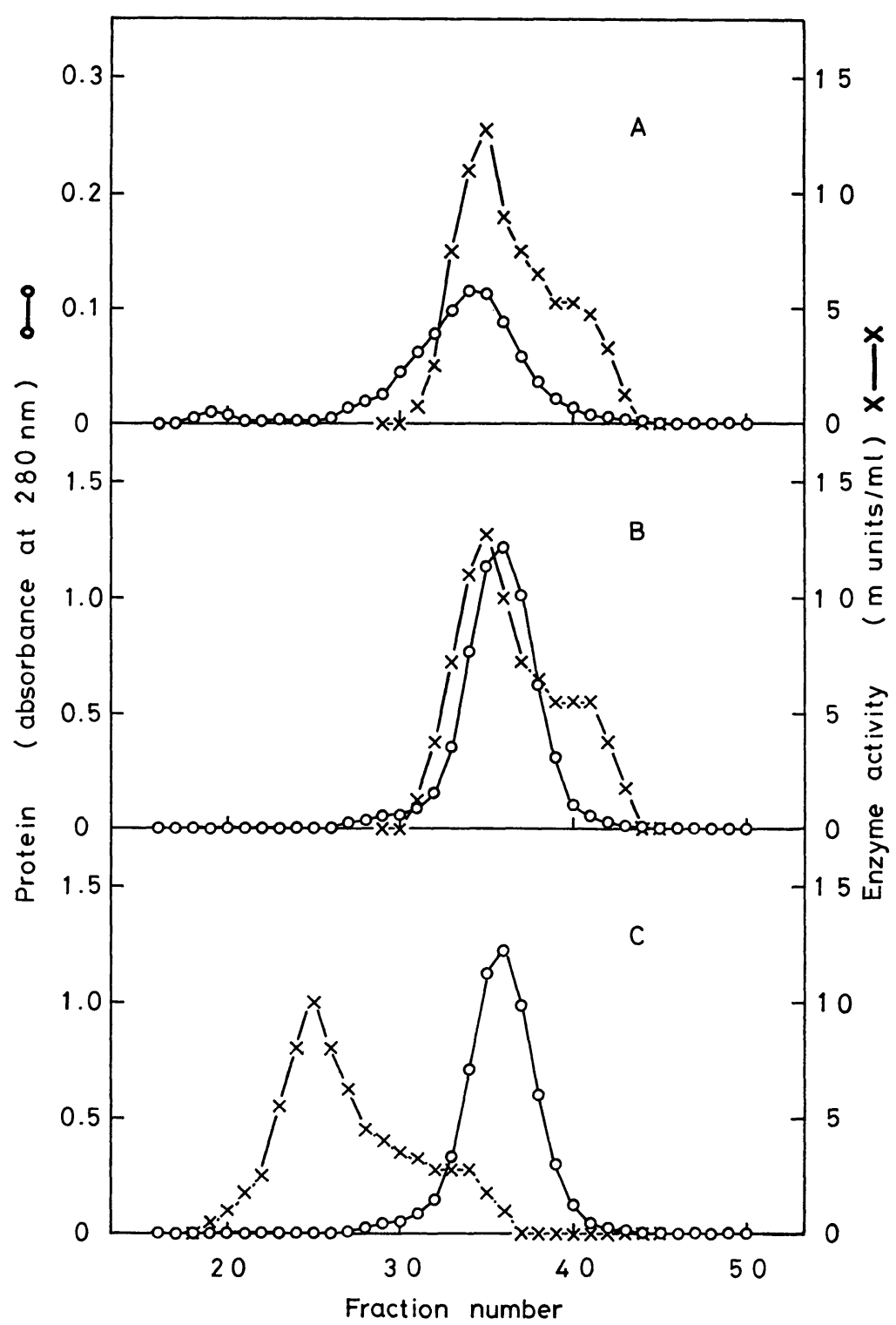

Fig. 3. Elution diagrams on Ultrogel AcA 34 of (A) starfish H6PD, 0.24 units; (B) starfish H6PD, 0.24 units, incubated with $2.4 \mathrm{ml}$ of normal IgG fraction and (C) starfish H6PD, 0.24 units, incubated with $1.5 \mathrm{ml}$ of anti-H6PD IgG fraction for $3 \mathrm{~h}$ at $4^{\circ} \mathrm{C}$. Samples were placed on a $2.5 \times 95 \mathrm{~cm}$ column and eluted with $20 \mathrm{mM}$ tris- $\mathrm{HCl}$ buffer, pH 7.4 containing $1 \mathrm{mM}$ EDTA and $0.5 \mathrm{M}$ ammonium sulfate. The flow rate was $30 \mathrm{ml}$ per hour and fractions of $10 \mathrm{ml}$ were collected. Enzyme activity was assayed at $21^{\circ} \mathrm{C}$ and $\mathrm{pH} 10.0$ with G6P and NADP as substrates. 


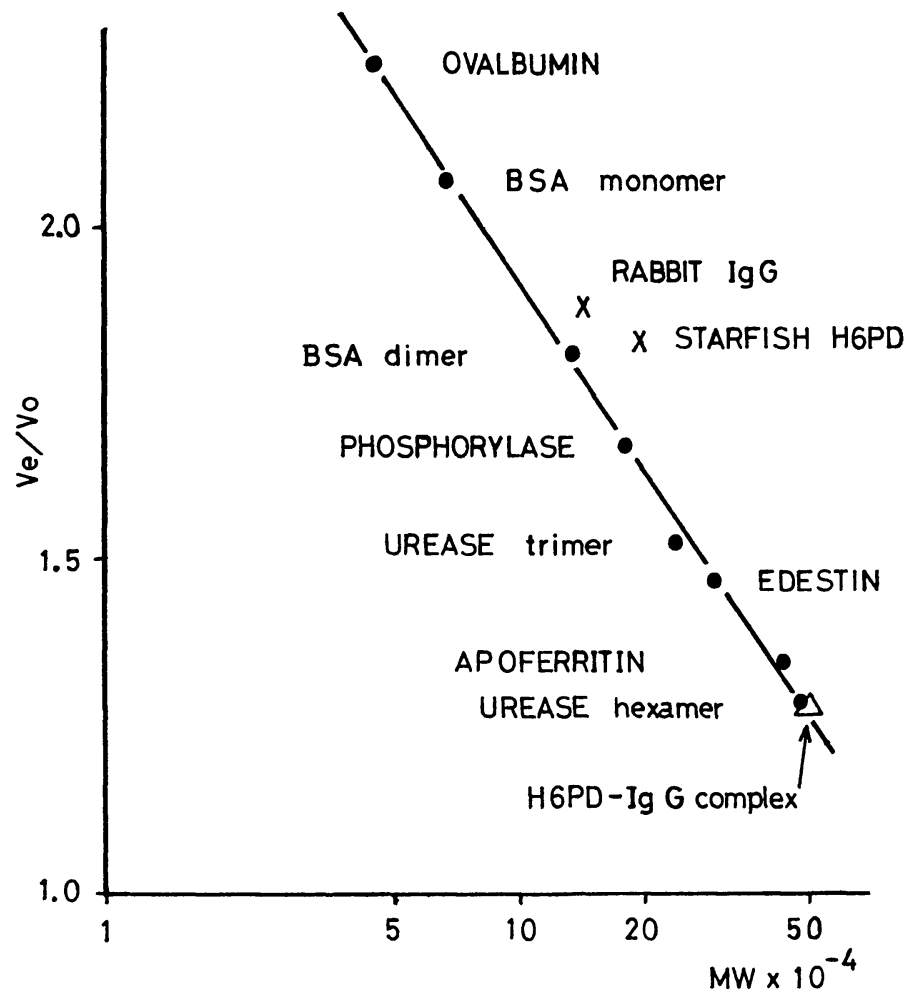

Fig. 4. Plot of elution volume, $\mathrm{V}_{\mathrm{e}} /$ void volume, $\mathrm{V}_{0}$ against $\log$ (mol. wt.) for proteins on a Ultrogel AcA 34 column $(2.5 \times 95 \mathrm{~cm})$. Standard proteins used were: ovalbumin (Sigma), 45,000; bovine serum albumin (Armour), monomer, 67,000, dimer, 134,000; rat skeletal muscle phosphorylase b, 185,000; hemp seed edestin (Nakarai), 300,000; jack bean urease (Nakarai), trimer, 240,000, hexamer, 480,000; horse spleen apoferritin, 443,000. Apoferritin was prepared from ferritin (ICN) by dialyzing against $2 \%$ ammonium sulfate- $0.2 \%$ sodium hydrosulfite (Kato et al. 1968). Ferritin and apoferritin were eluted from a Ultrogel column with very nearly the same volume of effluent.

The results showed that the antibody had the potency to activate the G6P dehydrogenating activity and that to inhibit the deoxyG6P dehydrogenating activity of fish H6PD (Fig. 2C), as well as the potency to reduce the electrophoretic mobility of fish H6PD. It is thus reasonable to assume that the antibody bound to starfish H6PD is the one specific for fish H6PD.

In conclusion, the evidence presented in this report supports the view that starfish and crucian carp H6PD are immunologically related, and hence might be homologous enzymes.

\section{SUMMARY}

It has been demonstrated by polyacrylamide gel electrophoresis and gel filtration on Ultrogel AcA 34 that rabbit antibody elicited to crucian carp hexose 6-phosphate 
dehydrogenase cross-reacts with starfish hexose 6-phosphate dehydrogenase. This supports our previous assumption that vertebrate and starfish hexose 6-phosphate dehydrogenases are homologous molecules.

\section{ACKNOWLEDGMENTS}

This work was supported by grants 134050 and 154255 from the Ministry of Education.

\section{LITERATURE CITED}

Beutler, E., and M. Morrison, 1967 Localization and characteristics of hexose 6-phosphate dehydrogenase (glucose dehydrogenase). J. Biol. Chem. 242: 5289-5293.

Campbell, J. H., J. A. Lengyel, and J. Langridge, 1973 Evolution of a second gene for $\beta$-galactosidase in Escherichia coli. Proc. Natl. Acad. Sci. U.S.A. 70: 1841-1845.

Hori, S. H., and Y. Sado, 1974 Purification and properties of microsomal glucose 6-phosphate dehydrogenase (hexose 6-phosphate dehydrogenase) of rat liver. J. Fac. Sci. Hokkaido Univ. Ser. 6, Zool. 19: 515-529.

Hori, S. H., S. Yonezawa, Y. Mochizuki, Y. Sado, and T. Kamada, 1975 Evolutionary aspects of animal glucose 6-phosphate dehydrogenase isozymes. In "Isozymes" (C. L. Markert, ed.), Vol. 4, pp. 839-852. Academic Press, New York.

Kato, T., S. Shinjo, and T. Shimada, 1968 Isolation and properties of ferritin from tuna fish (Thunnus obesus) spleen. J. Biochem. 63: 170-175.

Kimura, H., and M. Yamashita, 1972 Studies on microsomal glucose-6-phosphate dehydrogenase of rat liver. J. Biochem. 71: 1009-1014.

Mandula, B., S. Srivastava, and E. Beutler, 1970 Hexose-6-phosphate dehydrogenase: distribution in rat tissues and effect of diet, age and steroids. Arch. Biochem. Biophys. 141: 155-161.

Matsuoka, N., Y. Mochizuki, and S. H. Hori, 1977 Homology of starfish and vertebrate hexose 6-phosphate dehydrogenases. J. Fac. Sci. Hokkaido Univ. Ser. 6, Zool., in press.

Mochizuki, Y., and S. H. Hori, 1976 Hexose 6-phosphate dehydrogenase in starfishes. Comp. Biochem. Physiol. 54B: 489-494.

Ohno, S., H. W. Payne, M. Morrison, and E. Beutler, 1966 Hexose-6-phosphate dehydrogenase found in human liver. Science 153: 1015-1016.

Rutter, W. J., 1965 Enzymatic homology and analogy in phylogeny. In "Evolving genes and proteins" (V. Bryson and H. J. Vogel, eds.) pp. 279-291.

Sado, Y., and S. H. Hori, 1976 Properties of hepatic hexose 6-phosphate dehydrogenase and glucose 6-phosphate dehydrogenase from fishes and amphibians. J. Fac. Sci. Hokkaido Uuiv. Ser. 6, Zool. 20: 277-287.

Srivastava, S. K., and E. Beutler, 1969 Auxiliary pathways of galactose metabolism. J. Biol. Chem. 244: 6377-6382.

Stegeman, J. J., and E. Goldberg, 1971 Distribution and characterization of hexose-6-phosphate dehydrogenase in trout. Biochem. Genet. 5: 579-589.

Yamauchi, T., and E. Goldberg, 1973 Glucose 6-phosphate dehydrogenase from brook, lake and splake trout: An isozymic and immunological study. Biochem. Genet. 10: 121-134. 